\title{
FUZZY-LIKERT SCALE BASED ASSESSMENT OF MARKETING RISK FACED BY THE HYBRID RICE GROWERS OF BANGLADESH
}

\begin{abstract}
A. K. M. Kanak Pervez ${ }^{1}$, Md. Ektear Uddin', Ashfaq Ahmad Shah', Foyez Ahmed Prodhan', Md. Mohhiuddin Sheikh
\end{abstract}

*Corresponding authorE-mail:kp@ru.ac.bd

\begin{abstract}
A R T I C LE IN F O
Original Article

Received: 10 September 2018

Accepted: 18 January 2019

doi:10.5937/ekoPolj1901009K

UDC 658.8:633.18(549.3)

Keywords:

Defuzzification value, food security, fuzzy-Likert scale, hybridization, middleman

JEL: Q12, Q13, Q16

A B S T R A C T

The primary concentration of this study was to assess the marketing risks faced by hybrid rice growers and explore the trajectories. With this notion, data were collected from randomly selected 300 hybrid rice growers in purposively chosen areas with the application of a structured interview schedule and conducting five focus group discussions with the farmers. The study identified seven key risks responsible for the poor marketing of hybrid rice in Bangladesh. Perceived marketing risks were assessed by farmer's opinion on likelihood and severity of each risk source through using a fuzzy-Likert scale. According to the finding 'high fluctuation of hybrid rice price' was the most serious risk in hybrid rice marketing in Bangladesh. The regression result found several socio-demographic factors of the farmers are significantly related with perceived risk. This study, therefore, suggests government taking propolicies for hybrid rice growers organized around farmers' those socio-demographic characteristics for minimizing marketing risk.
\end{abstract}

(C) 2019 EA. All rights reserved.

1 A.K.M. Kanak Pervez, Ph.D, Assistant Professor, Dept. of Agronomy \& Agricultural Extension, University of Rajshahi, Bangladesh, Phone: +8801706687967, e-mail: kp@ ru.ac.bd, ORCID ID (https://orcid.org/ 0000-0001-7413-9337)

2 Md. Ektear Uddin, Ph.D., Associate Professor, Dept. of Agricultural Extension \& Rural Development, Patuakhali Science and Technology Uniersity, Dumki, Patuakhali, Bangladesh, Phone: +8801717522941, e-mail: ektearcau@gmail.com

3 Ashfaq Ahmad Shah, Ph.D., Assistant Professor, Development Studies Department, School of Social Sciences and Humanities (S3H), National University of Sciences \& Technology (NUST), Islamabad 44000, Pakistan, email: ahmad.ashfaq1986@gmail.com

4 Foyez Ahmed Prodhan, M.S., Dept. of Agricultural Extension and Rural Development, Bangabandhu Sheikh Mujibur Rahman Agricultural University, Gazipur, Bangladesh, email: foyez@bsmrau.edu.bd

5 Md. Mohiuddin Sheikh, M.S., Ph.D Candidate, Dept. of Extension Education, Punjab Agricultural University, India, Phone: +8801718282681, e-mail: sheikhm38@gmail.com 


\section{Introduction}

Bangladesh is one of the peak densely inhabited nations in the world, where around 1,237.51 people reside per square kilometer (EC, 2015). Despite very low per capita land holding (approximately 0.048 hectares, WB, 2015), the cultivable land is declining at 1 per cent per year. FAO (1993) estimated, about 0.07 hectares of arable land per person is required for a year-round vegetarian diet and excluding various land degradations, with sufficient availability of water. Therefore, it is challenging to meet future food security needs. Also, the high population growth rate makes the country vulnerable to future food security. It is assumed in 2050, the population of the country will be 1.5 times than the present population (UN, 2010). Currently, 35\% of the people are living under the food consumption poverty line (Kashem \& Faroque, 2011). Bangladesh is the fifth most vulnerable nation to climate change (the Daily Star, 2011) and affecting the crop production in Bangladesh. Usually, a disastrous cyclone attacks the country once every three years (GoB, 2008). Bangladesh has been experiencing around 6-20 mm sea level rise in every year (Siddique, 2015) and around $40 \%$ of productive land in the southern region will be lost in a $65 \mathrm{~cm}$ sea level rise by the $2080 \mathrm{~s}$ (WB, 2013).

To face the present challenges, the country has initiated some horizontal and vertical programs for increasing food crop production, e.g., mixed farming, relay cropping, multi-storied cropping together with high yielding hybrid varieties. Hybrid rice production was initiated in Bangladesh in 1998 to increase the total rice production due to excessive demand for rice for a growing population to meet the food security. As, rice is the staple food, supplying 76\% calorie intake $66 \%$ protein (Bhuiyan et al., 2002) and 43.6\% of labor force (BBS, 2010, HIES, 2009), 9.5\% GDP (Alam \& Islam, 2013). Initially, yield advantages of hybrid rice motivated many farmers to adopt it, but very soon the number of hybrid rice farmers and area dropped dramatically. After the introduction of hybrid rice in 1998-99, the area within nine years increased around 4263\% (Rashid et al., 2011): then suddenly, popularity declined. In 2007-08 the hybrid rice area was 0.80 million hectare whereas in 2013-14 it dropped to 0.63 million hectares (Parvez, 2014) which is only around $7.05 \%$ of the total area (Krishi Dairy, 2018). Researchers have identified various risks were inhibiting the adoption of hybrid rice production in Bangladesh (McFall et al., 2013; Shah et al., 2015; Pervez, 2018). Among the risks, the marketing risks are the most significant. Due to these, many farmers are losing their significant profits and even, sometimes, their investments. Numerous intermediaries are dominating the hybrid rice market. Therefore, farmers are not getting a fair price for their produce: instead, the intermediaries are getting the lion share of benefit (Shaikh, 2008). Furthermore, market instability and failure are widespread in the case of hybrid rice. Therefore, the current study was intended to: (i) discover marketing risks in hybrid rice production in Bangladesh; (ii) score the Perceived Marketing Risk (PMR) and rank; and (iii) find out the relationship between socio-demographic characteristics and PMR. 


\section{The market-related risk in agriculture in Bangladesh}

There are five separate risk factors in the field of agriculture: (i) production or yield risk; (ii) marketing risk: (iii) credit risk; (iv) personal risk; and (v) financial risk (Pervez et al., 2016). In Bangladesh, the main risks in agriculture come from price or marketrelated activities. The gap between the selling price from farmers and the consumers' purchasing price is exceptionally high (Abdullah \& Hossain, 2013) because of the presence of intermediaries in the market. Due to lack of storage facilities and extreme poverty, peasants are bound to sell their products immediately after the harvest. Therefore, in a particular season, a specific crop floods the markets, and ultimately the price diminishes and sometimes goes below the cost of production.

On the other hand, farmers in Bangladesh generally invest in by receiving loans from mohajons (rural loan broker) (Pervez et al., 2016). Mohajons usually claim a very high interest, sometimes 1.5 or 2 times higher than the loan amount after a crop season (90120 days); their business is locally called dera shud (150\% interest) and duna shud (double repayment) (Islam et al., 2012). Sometimes farmers go to NGOs for a loan, but NGOs still need formal procedures: for example, membership of the respective NGO, pay dues and start to deposit money. Therefore, poor farmers hardly find the benefits from microcredit for crop production (Khatun et al., 2013).

Furthermore, the marketing structure and the transport facilities for farmers are also fragile, and the peasants have minimum access to the urban market. This plight creates space for the middlemen (Chowdhury, 2011; Khan, 2012). Due to the excessive presence of intermediaries in the market farmers cannot directly sell their commodities to ultimate consumers (Matin et al., 2008). Therefore, farmers go to arotder (rural wholesaler) to sell their product. Arotder also offers a little price to the farmers (Pervez et al., 2016).

Other marketing risks come from the political turmoil of the country. A general strike ('hartal') creates an obstacle to selling farmers' products in the market, due to violence in the streets and blockages of the road, but people in the cities are forced to spend a higher amount of money because of limited supply. Therefore, the profit again goes to middlemen mostly, and farmers lose out.

\section{Materials and methods}

Hybrid rice production in Bangladesh is geographically localized. Even in a single district, all sub-districts (Upazilla) have not entered into the hybrid rice cultivation program. Therefore, the study was conducted in purposively selected two different Upazillas namely; Khoksa and Debidwar from Kustia and Comilla districts in Bangladesh, respectively. The significant reason behind purposive selection is the number of farmers and the areas under hybrid rice cultivation in the areas has been declining with time. The familiarity of the researchers with the study areas and extension agents is also one of the reasons. A total of 1500 farmers (households) were (20142015) cultivating hybrid rice which was considered as the population of the study. The 
list of farmers was collected from the two Upazilla agriculture offices. From the list of farmers, we used a random sampling (using the table of random numbers) of $20 \%$ of the population: therefore, the sample size of the study is 300 .

The marketing risk sources ( seven risks) were identified by conducting five Focus Group Discussions (FGDs) with hybrid ric farmers. Data were collected from the hybrid rice farmers by carrying out structured personal interviews, from January, 2015 to June, 2015. To assess the reliability and consistency of the instrument, Cronbach alpha was calculated from the pre-test results of the seven items. The reliability of statements showed an alpha value of more than 0.70 , the accepted value (Nunnally, 1978).

Farmers' socio-demographic characteristics, e.g. age, education, annual family income, family farm size, watching /listening to agriculture-related programs on TV/radio, source of hybrid rice seeds, rice selling in the Public Procurement (PP) and loan from NGO/ NGOs were taken as the independent variables of the study (Table 3). The dependent variable of the study was Perceived Marketing Risk (PMR) in hybrid rice production.

\section{Measurement of PMR using Fuzzy-Likert Scale}

The relationship among risk $(\mathrm{R})$, hazard $(\mathrm{H})$ and vulnerability $(\mathrm{V})$ can be expressed in a mathematical equation presented by Soussan \& Arriens (2004) and Kirilenko et al., (2004).

$$
\mathrm{R}=\mathrm{f}(\mathrm{H} \times \mathrm{V})
$$

Similarly, German sociologist Ortwin Renn defined 'risk' (Renn, 2008) as the multiplication of the probability of an event occurrence and its significance level of potentially unfavorable condition. Therefore the term 'risk' can be described mathematically as:

$$
\text { Risk }=\text { Probability of an event } \times \text { Significance (loss due to the event) }
$$

To measure PMR, we used a fuzzy-Likert scale instead of the traditional Likert scale. Although the Likert scale is the most commonly used psychometric scale in the arena of survey research, we used a modified Likert scale to avoid the limitations of the traditional Likert scale. Generally, attitudes towards a statement are vast and have a multi-dimensional continuum. The Likert scale is a single-dimensional and gives only 5 to 10 different options of choice to the respondents. Thus, it is challenging to measure the real attitude of participants. Likert scale assumes equal differences between two consecutive scale points (e.g., strongly agree=5, agree=4). Social scientists like Cohen et al., (2000) have argued that this is illegitimate: to assume the same difference between two consecutive scale points.

Another significant constraint of the Likert scale is that it is based on a closed format for the responses (Hodge \& Gillepie, 2003). Therefore Li (2013) argued that the scale forced the respondents to choose only from given options, whether or not they represented the respondent's true opinions. To overcome the limitation of existing Likert scale, Li 
(2013) suggested a Likert scale based on fuzzy sets. The fuzzy set concept was first introduced by L.A. Zadeh (Zadeh, 1965). Although uses of fuzzy sets in engineering and mathematics have been widely successful, their use in social sciences has been quite limited. These sets have essential applications in the field of social sciences (Ragin, 2000; Smithson \& Verkuilen, 2006; Rivza \& Rivza, 2013; Uddin, 2012). As, a fuzzy risk matrix is a potent tool for semi-quantitative risk assessment, as proved by Markowski \& Mannan (2008), to handle different process activities of hazardous events (Portik \& Pokoradi, 2014).

From the definition of the risks (equation 2) we know, risks have two different sides: an uncertainty which can be measured with 'probability' or 'likelihood' and the 'impact' or 'consequences'. Therefore, for obtaining better results, we applied a two-dimensional scale in our research. Five points fuzzy-Likert scale for probability measurements (Table 1) and another five point's fuzzy-Likert scale for impact assessment (Table 2) were used (Rivza \& Rivza, 2013; Pervez, 2018). Previously, in some studies, farmers were asked to rate the risk level. However, Botterill \& Mazur (2004) argued that risks should be identified by its' probability and consequences.

Table 1: A triangular fuzzy scale for evaluation risk probability

\begin{tabular}{|l|l|r|}
\hline $\begin{array}{c}\text { Linguistic } \\
\text { scale }\end{array}$ & \multicolumn{1}{c|}{ Characterization } & \multicolumn{1}{c|}{ Triangular fuzzy scale } \\
\hline Unlikely & Could happen only under rare conditions & $(0,0.125,0.25)$ \\
\hline Seldom & Could happen though unlikely (once in few years) & $(0.15,0.30,0.45)$ \\
\hline Occasional & Could happen once in a year & $(0.35,0.50,0.65)$ \\
\hline Likely & Could happen once in every season & $(0.55,0.70,0.85)$ \\
\hline Frequent & Could happens two or more time in every seasons & $(0.75,0.875,1.0)$ \\
\hline
\end{tabular}

Source: Rivza and Rivza (2013), Modified; Pervez (2018)

Table 2: A triangular fuzzy scale for evaluation of the significance (impact) of risks

\begin{tabular}{|l|l|r|}
\hline $\begin{array}{l}\text { Linguistic } \\
\text { scale }\end{array}$ & Characterization & \multicolumn{1}{|l|}{ Triangular fuzzy scale } \\
\hline Negligible & Up to 1\% from the total budget & $(0,0.0075,0.015)$ \\
\hline Minor & $1-5 \%$ from the total budget & $(0.005,0.025,0.055)$ \\
\hline Moderate & $5-10 \%$ from the total budget & $(0.045,0.0775,0.11)$ \\
\hline Critical & $10-25 \%$ from the total budget & $(0.09,0.195,0.30)$ \\
\hline Catastrophic & Above 25\% from the total budget & $(0.20,0.60,1.0$ \\
\hline
\end{tabular}

Source: Rivza \& Rivza, (2013), Modified; Pervez (2018)

Fuzzy values for probability and consequences were multiplied according to fuzzy multiplication law $(\mathrm{A} \otimes \mathrm{B}=(\mathrm{a} 1 \otimes \mathrm{b} 1, \mathrm{a} 2 \otimes \mathrm{b} 2, \mathrm{a} 3 \otimes \mathrm{b} 3))$ (Habibi et al., 2015). Thereby, we obtained new fuzzy values: but these values are not real numbers. So, we need defuzzification of the triangular fuzzy values. Among the different defuzzification methods, we used centroid methods (Ross, 2005). The defuzzification value for each item was used as the PMR score for that item (Yu \& Lee, 2012; Kadir et al., 2013). 
Finally, all scores for each risk source were summed to get the total PMR score of an individual farmer. The defuzzification value and the frequency distribution of the farmers' level survey on PMR sources are shown in appendix A.

\section{Results and Discussions}

The results of the descriptive analysis are summarized in table 3. According to the findings, the majority of the respondents were young to middle-aged. Older people in Bangladesh generally are not interested in taking new knowledge as an innovation (Feder et al., 1985). Quddus (2012) also found that the probability of farmer's adoption of new technologies decreased with their age in Bangladesh.

Among 300 hybrid rice farmers, only 31 were women. Although women in Bangladesh are primarily responsible for food production, the land is generally possessed or controlled by the men, and therefore women's productivity is often constrained (Sarwar, 2007). Women are also burdened with domestic duties which limit their time and energy to spend on agriculture. Furthermore, they are generally unable to take the risk of high expenditure. Rural women prefer cultivating by using indigenous knowledge for a long time because of less empowerment, less education and low-level technological knowhow (Pervez et al., 2015).

Most of the hybrid rice farmers had finished only secondary education. Very few hybrid rice farmers have completed their bachelor's degree. This is because educated people in the country are not interested in taking farming as a profession.

Annual family income of the hybrid farmers is mostly medium. Farmers with lowincome levels are unable to take risks. On the other hand, rural people with higher income are not interested in conducting direct farming. They provide leasing their land to the landless and marginal farmers, which is entirely risk-free farming. The rich generally make unfair agreements with the peasants (Pervez et al., 2016) and risks usually go to the peasants.

Hybrid rice farmers were classified by their family farm size, as guided by BBS (1993). Most of the farmers were under 'marginal,' 'small' and 'medium' farmer's categories: only two farmers were 'large', and there are no hybrid rice farmers under 'landless' category. Landless and marginal farmers cannot allocate their land for the hybrid rice farming because of land shortage and inability to take the risk.

Most of the farmers do not watch/ listen to the agricultural programs on TV/radio. Farmers usually cannot allocate the time for watching/ listening to this kind of applications (Pervez, 2018): some cannot adjust to the specific time of these programs, as farming is not conducted on a timetable. Others are not interested in these programs: they prefer to enjoy drama or listening to music.

Only around one-fourth of the farmer gets their hybrid rice seed from the government sources. Low infrastructure and the inability of the government to produce a large-scale hybrid rice seed bound farmers to go for expensive seed sources. 
Furthermore, only a few farmers get opportunities to sell rice in public procurement (PP). Therefore, most of the hybrid rice farmers do not get a fair price for their product. Extreme corruption in PP prevents farmers to sell there as they do not have the money to bribe the officials to accept their rice (Pervez, 2018). Rice marketing channels are dominated by the middlemen in Bangladesh (Sultana, 2012). Therefore, farmers get lower prices, but in the polished rice market, the cost of rice is very high. Thus, most of the profits go to intermediaries (Pervez et al., 2017).

Around $70 \%$ of the farmers could not obtain a bank loan for farming. Generally, farmers have little access to the bank. Therefore most of the farmers go to NGOs for a credit, which is expensive because of very high-interest rates. Many researchers have argued that NGO services are not reaching the extremely poor (Khatun et al., 2013).

Table 3: Socio-demographic characteristics of hybrid rice farmers

\begin{tabular}{|c|c|c|c|c|c|}
\hline \multirow{2}{*}{$\begin{array}{c}\text { Variable and scoring } \\
\text { technique }\end{array}$} & \multicolumn{2}{|l|}{ Categories } & \multirow{2}{*}{ SD } & \multirow{2}{*}{ Mean } & \multirow{2}{*}{ Mode } \\
\hline & $n=300$ & $\%$ & & & \\
\hline Age (1 for each year) & $\begin{array}{l}\text { Young (up to 34) - 55 } \\
\text { Middle aged (35-57)- } 199 \\
\text { Old (more than 57)- } 46 \\
\end{array}$ & $\begin{array}{l}18.33 \\
66.33 \\
15.33 \\
\end{array}$ & 11.50 & 45.41 & 55 \\
\hline $\begin{array}{l}\text { Gender ( } 0 \text { for female } 1 \text { for } \\
\text { male) }\end{array}$ & \begin{tabular}{|l|} 
Male -269 \\
Female- 31
\end{tabular} & $\begin{array}{l}89.67 \\
10.33\end{array}$ & - & - & 1 \\
\hline $\begin{array}{l}\text { Education ( } 1 \text { for each year } \\
\text { of schooling) }\end{array}$ & $\begin{array}{l}\text { Low (up to 5) - 70 } \\
\text { Medium (6-12)- 215 } \\
\text { High (more than 12)- } 15 \\
\end{array}$ & $\begin{array}{r}23.33 \\
71.67 \\
5.00 \\
\end{array}$ & 3.52 & 8.07 & 8 \\
\hline $\begin{array}{l}\text { Annual family Income } \\
\text { ( } 0000 \mathrm{BDT})\end{array}$ & $\begin{array}{l}\text { Low (below 13.72) - } 76 \\
\text { Medium (13.72-33.56)- } 186 \\
\text { High (above 33.56)- } 61\end{array}$ & $\begin{array}{l}25.33 \\
62.00 \\
20.33\end{array}$ & 9.92 & 23.64 & 30 \\
\hline Farm Size (Hectare) & $\begin{array}{l}\text { Landless (up to } 0.02 \text { ha)- } 0 \\
\text { Marginal (0.021 - } 0.2 \text { ha)- } 35 \\
\text { Small (0.21-1 ha)- } 204 \\
\text { Medium (1.1-3 ha) - } 59 \\
\text { Large (above } 3 \text { ha)- } 2 \\
\end{array}$ & $\begin{array}{r}0.00 \\
11.67 \\
68.00 \\
19.67 \\
0.67 \\
\end{array}$ & 0.64 & 0.72 & 0.40 \\
\hline $\begin{array}{l}\text { Listening/watching } \\
\text { agricultural program on } \\
\text { radio/TV }(0=\text { Not listen/ } \\
\text { watch, } 1=\text { Watch/listen once } \\
\text { in a month, } 2=\text { Once in a } \\
\text { week, } 3=\text { More than once in } \\
\text { a week })\end{array}$ & $\begin{array}{l}\text { Not listen/watch - } 141 \\
\text { Watch/listen once in a month- } 66 \\
\text { Once in a week - } 44 \\
\text { More than once in a week - } 49\end{array}$ & $\begin{array}{r}47.0022 .00 \\
14.67 \\
16.33\end{array}$ & 1.12 & 1.00 & 0 \\
\hline $\begin{array}{l}\text { Source of hybrid rice seed } \\
\text { ( } 0 \text { for non-government, } 1 \text { for } \\
\text { government source) }\end{array}$ & $\begin{array}{l}\text { Non-governmental source }-215 \\
\text { Governmental source - } 85\end{array}$ & $\begin{array}{l}71.67 \\
28.33\end{array}$ & - & - & 0 \\
\hline $\begin{array}{l}\text { Rice selling in Public } \\
\text { Procurement (PP) } 1,0 \text { for } \\
\text { others ) }\end{array}$ & $\begin{array}{l}\text { Could not sell rice in PP- } 205 \\
\text { Could sell rice in PP - } 95\end{array}$ & $\begin{array}{l}68.33 \\
31.67\end{array}$ & - & & 0 \\
\hline $\begin{array}{l}\text { Bank loan ( } 0 \text { for no } \\
\text { recipient, } 1 \text { for recipient })\end{array}$ & $\begin{array}{l}\text { Could not obtained bank loan } \\
-212 \\
\text { obtained bank loan- } 88\end{array}$ & $\begin{array}{l}70.67 \\
29.33\end{array}$ & - & & 0 \\
\hline
\end{tabular}


By mean and the standard deviation, the farmers' PMR score was categorized into three (Table 4). The highest proportion of the farmers perceived under medium level risks (70\%) whereas $17.33 \%$ and $12.67 \%$ of the respondents perceived the serious and little risks, respectively.

Table 4: Distribution of the respondents by marketing risk score

\begin{tabular}{|l|c|c|c|c|}
\hline Categories & $\boldsymbol{f}(\boldsymbol{n}=\mathbf{3 0 0})$ & $\boldsymbol{\%}$ & $\boldsymbol{M}$ & $\boldsymbol{S D}$ \\
\hline Low risky situation & 38 & 12.67 & & \\
\hline Medium risky situation & 210 & 70 & 0.87 & 0.54 \\
\hline High risky situation & 52 & 17.33 & & \\
\hline
\end{tabular}

The rank order of the risk sources is represented in table 5. Among the seven risk sources 'high price fluctuation of hybrid rice' obtained the highest score. The other catastrophic risk sources were 'refusal of hybrid rice cultivation due to high seed price', 'scarcity of hybrid rice seed during seasons', 'high economic losses due to the excessive presence of middlemen in hybrid rice marketing channel' ranked second, third, and fourth, respectively.

Table 5: PMR sources and their rank order according to survey data

\begin{tabular}{|c|l|r|c|}
\hline $\begin{array}{l}\text { SI. } \\
\text { No. }\end{array}$ & Sources of marketing risks & Score & Rank \\
\hline 1 & The scarcity of quality hybrid rice seeds during seasons & 35.3847 & 3 \\
\hline 2 & Refusal of hybrid rice cultivation by farmers due to high seed price & 50.0727 & 2 \\
\hline 3 & High price fluctuation of hybrid rice price & 57.0547 & 1 \\
\hline 4 & $\begin{array}{l}\text { High economic loss to farmers due excessive presence of middlemen in } \\
\text { the marketing channel }\end{array}$ & 33.7987 & 4 \\
\hline 5 & Fertilizer and pesticides market instability & 30.9982 & 5 \\
\hline 6 & $\begin{array}{l}\text { Dissonance of farmers to cultivate hybrid rice due to high irrigation } \\
\text { cost }\end{array}$ & 28.0253 & 7 \\
\hline 7 & Poor demand of hybrid rice due to over-production of inbred rice & 28.1888 & 6 \\
\hline
\end{tabular}

Bangladeshi people are habituated to take flaky and non-sticky rice in their meals. Hybrid rice is stickier than the inbred rice because of low amylose content. Therefore market demand for hybrid rice in Bangladesh is deficient. On the other hand, the price goes high when there is an extreme crisis of inbred rice, thus low market signal to farmers to cultivate or not to cultivate. The high cost of hybrid rice seeds is another crucial problem in hybrid rice marketing in Bangladesh. Lack of government support to the farmers in seed production and poor government infrastructure create seed crises during the sowing time. Finally, the price increases sharply. Millers or intermediaries are very interested in buying these types of rice because of the low price. Millers purchase hybrid rice at a meager price and then mix it with other inbred rice. They then sell polished rice in the name of inbred rice. Thus, the profit gainers usually are millers or middlemen (Pervez et al., 2016).

The regression result (Table 6) shows that the relationship between the dependent and independent variables. Education has a significant negative association with PMR. Education can broaden the outlook and make one less fearful of risk. Educated farmers 
can enter the market information via different media. Therefore, education helps to reduce the perception of risks in hybrid rice production. Nadhomi et al., (2013) found a similar relationship between schooling and perceived risk in soil erosion. The farmers with higher family incomes are capable of managing the risks because of their available resources. Thus, farmers with high family income perceive low marketing risks. Income generation reduces disaster risk perception (UN, 2009). The farmers who listen to/ watch agricultural programs/news on TV/radio can get the recent market information. Therefore, they faced fewer risks in the marketing of hybrid rice. Access to PP of hybrid rice provides a fair price for hybrid rice, which enables farmers to manage marketing risks. So, 'rice selling in PP' has a significant negative relation with PMR. Furthermore, the farmers who got the loan from the bank are capable of managing risks. Thus, this variable shows a significant negative association with marketing risks. In other studies, it has been detected that public investment in farming can reduce risks (Miller, 2008). The source of hybrid rice seed shows a significant positive relation which means the farmers who got the seed from government sources perceive that they are more vulnerable to risks. This is because, government sources provide their seeds without adequate support. On the other hand, private businesses are competitive. Some companies are providing technical assistance to increase yields, which can help to develop sales. Therefore, farmers who got seed from private companies felt they could manage risks better in comparison with the farmers who got seed from government sources.

Table 6: Regression results for PMR and socio-demographic characteristics of hybrid rice farmers

\begin{tabular}{|c|c|c|c|c|c|}
\hline Variables & $B$ & $S E$ & beta & $\mathrm{t}$ & Sig. \\
\hline (Constant) & 1.646 & .118 & & 13.935 & .000 \\
\hline Age & .001 & .002 & .012 & .311 & .756 \\
\hline Gender & .123 & .068 & .069 & 1.808 & .072 \\
\hline Educational level & -.041 & .008 & -.264 & -4.827 & .000 \\
\hline Annual family income & -.019 & .003 & -.339 & -6.792 & .000 \\
\hline Farm size & .021 & .034 & .025 & .621 & .535 \\
\hline $\begin{array}{l}\text { Watching/listening agricultural programs on } \\
\text { TV/radio }\end{array}$ & -.094 & .027 & -.194 & -3.419 & .001 \\
\hline Source of hybrid rice seed & .191 & .067 & .158 & 2.859 & .005 \\
\hline Rice selling in public procurement process & -.231 & .064 & -.198 & -3.619 & .000 \\
\hline Loan from bank & -.147 & .067 & -.123 & -2.200 & .029 \\
\hline
\end{tabular}

\section{Conclusions}

Although the Likert scale is the most commonly used scale in social sciences, scientists hardly criticized the shortcomings of the scale, particularly a problem where there are multidimensional continuums. The Likert scale uses close format for responses. Also, the scale applies a shaped edged difference between two scale-points which unable to explain semi-quantitative reactions. Therefore, for more precise and satisfactory assessment the research recommends fuzzy theory based Likert scale. 
This study identified seven key marketing risks through discussion with hybrid rice farmers. These risks were ranked by likelihood and severity of an incidence by the farmer's assessment. By their assessment, we found that the main risk comes from the price volatility of hybrid rice. Other severe risks in hybrid rice production in Bangladesh are high seed price and the extreme scarcity of quality seed in the market during rice seasons. Thus most of the farmers discontinue hybrid rice cultivation or do not adopt hybrid rice cultivation as an innovation. This study also found that educated, income rich, large farmers who enjoy agricultural programs in mass media and sell hybrid rice in PP faced fewer risks compared to the others.

By findings, the current research recommends i) boosting farm educational program, arranging income maximization program, motivating big farmers to participate in hybrid rice cultivation. ii) Organizing low-interest crop loan program with the due interference of state extension can significantly reduce the marketing risk of hybrid rice growers of Bangladesh. iii) The Government should develop proper marketing channels with a fair price and should increase the production of hybrid rice seeds by farmers, along with technical support, to reduce the risks among the farmers. iv) The Government also should ensure proper extension and training supports along with adequate and quality seed marketing with a subsidy. v) Controlling the middlemen in the marketing channel in a proper way. vi) To increase facilities for hybrid rice research and development, the government should establishment a separate Hybrid Rice Research Institute in Bangladesh.

\section{Conflict of interests}

The authors declare no conflict of interest.

\section{References}

1. Abdullah, M. \& Hossain, M.R. (2013). A new cooperative marketing strategy for agricultural products in Bangladesh, World Review of Business Research 3(3), $130-144$.

2. Alam, M.S. \& Islam, M.A. (2013). Long-term assessment of rice production scenario in Bangladesh: a macro dynamics, Bangladesh, J. Agril. Res. 38(2): 257-269.

3. BBS. (2010). Statistical Year Book of Bangladesh, Dhaka: Bangladesh Bureau of Statistics (BBS).

4. BBS. (1993). Statistical Yearbook of Bangladesh, Dhaka: Bangladesh Bureau of Statistics (BBS).

5. Bhuiyan, N. I., Paul D. N. R. \& Jabber, M. A. (2002). Feeding the Extra Millions. Proceedings of the BRRI-DAE Workshop on Experiences of HYV Rice Production in Bangladesh, Bangladesh Rice Research Institute, Gazipur.

6. Botterill, L. \& Mazur, N. (2004). Risk and Risk Perception: a Literature Review. Barton: Rural Industries Research and Development Corporation.

7. Chowdhury, M.I. (2011). Agrarian Transition and Livelihoods of the Rural Poor: Agricultural Product Market, Dhaka: Unnayan Onneshan. 
8. Cohen, L., Manison, L. \& K. Morisson. (2000). Research Methods in Education, London: Routledge Falmer.

9. EC (European Commission). (2015). Bangladesh ECHO Factsheet, Brussels: Humanitarian Aid and Civil Protection Department (ECHO).

10. FAO (Food and Agriculture Organization) (1993). Soil Loss Accelerating Worldwide, Rome: FAO.

11. Feder, G.R., Just, R.E. \& Zilberman, D. (1985). Adoption of agricultural innovation in developing countries: a survey, Economic Development and Cultural Change, 33(1): 255-298.

12. GoB (Government of Bangladesh) (2008). Cyclone Sidr In Bangladesh: Damage, Loss and Needs Assessment For Disaster Recovery and Reconstruction, Dhaka: Government of Bangladesh (GoB), Dhaka.

13. Habibi, A., Jahantigh, F. F. \& Sarafrazi, A. (2015). Fuzzy-delphi technique for forecasting and screening items, Asian Journal of Research in Business Economic and Management 5(2): 30-143.

14. HIES, (2009). Household Income Expenditure Survey (HIES), Dhaka: Bangladesh Bureau of Statistics.

15. Hodge, D.R. \& Gillespie D. 2003. Phrase completions: an alternative to Likert scales, Social Work Research, 27 (1):45-55.

16. Islam, M.M., Bhuiyan, M.N.K. \& Harun, M.Y. (2012). Development of value chain: an effective way of profitable duck farming in haor areas of Bangladesh, INFPD Good Practices of Family Poultry Production Note No 04. Retrieved from http://www.fao.org/3/a-aq631e.pdf ( July 31, 2018)

17. Kadir, M.K.A., Hines, E.L., Qaddoum, K. R., Collier, Dowler, E., Grant, W., Leeson, M.S., Iliescu, D., Subramanian, A., Richards, K., Merali Y., \& Napier, R.M.(2013). Food Security Risk Level Assessment: A Fuzzy Logic-Based Approach, Applied Art International, 27(1): 50-61.

18. Kashem, M. A. \& Faroque, M. A. A. (2011). A country scenarios of food security and governance in Bangladesh, J. Sci. Foundation, 9(1-2): 41-50

19. Khan, M.R.A. (2012). A proven model for achieving localized food security and farmers benefit protection, MPRA Paper No. 41383, Dhaka: Department of Agricultural Marketing.

20. Khatun M.A., Islam, M.A. \& Majumder, S. (2013). why some poor women in Bangladesh do not opt for micro-credit? Journal Bangladesh Agricultural University 11(2): 285-292.

21. Kirilenko, A.P., Alcamo, J., Golubev, G.N., Dronin, N.M. \& Endejan, M. (2004). Modeling the impact of climate changes on agriculture in Russia, Journal of Russian Academy of Sciences, 396(6): 819-822.

22. Krishi Diary, (2018), Dhaka: Agricultural Information Services.

23. Li, Q. (2013). A novel Likert scale based on fuzzy sets theory, Expert Systems Application, 40: 1609-1618. 
24. Markowski A. S \& Mannan, M.S. (2008). Fuzzy Risk Matrix, Journal of Hazardous Mathematics,156(1):152-57.

25. Matin, M.A., Baset, M.A., Alam, Q.M., Karim, M.R., Hasan, M.R. (2008). Mango marketing system in selected area of Bangladesh, Journal of Agricultural Research, 33 (3): 427-438.

26. McFall, W. Magnan, N. \& Spielman, D.J. (2013). Hybrid rice as a pro-poor technology? evidence from Bangladesh, Selected Paper prepared for presentation at the Agricultural \& Applied Economics Association's 2013 AAEA \& CAES Joint Annual Meeting, Washington, DC, August 4-6.

27. Miller, A., Dobbins, C., Pritchett, J., Boehlje, M. \& Ehmke. C. (2004), Risk management for farmers, Rome: Food and Agriculture Organization.

28. Miller, C. 2008. Risk mitigation and management for agricultural investment: investment and resource mobilization, Rome: Food and Agricultural Organization.

29. Nadhomi, D.L., Tenywa, J.S., Musali, P., \& Nakileza, B.R. (2013). Farmers' perception of erosion risk and its implication on the adoption of soil and water conservation practices. International Journal of Advance Agricultural Science and Technology, 2(1):28-44.

30. Nunnally, J. C. (1978). Psychometric theory, New York: McGraw-Hill.

31. Parvez, S. (2014 October, 3). Hybrid rice wins back popularity, The Daily Star.

32. Pervez, A.K.M.K. (2018). A study of risk management strategy for hybrid rice production in Bangladesh, Thesis diss., China Agricultural University.

33. Pervez, A.K.M.K., Gao, Q. \& Uddin, M.E. (2015). Rural women's awareness on indigenous technical knowledge: case of northern Bangladesh, Anthropologist, 21(3): 415-426.

34. Pervez,A.K.M.K., Gao, Q.\& Uddin. M.E. (2016). The management of agricultural risk in Bangladesh: a proposed process, Asian Journal of Agricultural Extension Economics \& Sociology, 12(1): 1-13.

35. Pervez, A.K.M.K., Gao, Q., Zeng, Y., \& Uddin, M.E. (2017). Hybrid rice: Bangladesh's failure and china's success, Journal of Agriculture and Ecology Research International, 10(1): 1-10.

36. Portik, T. \& Pokoradi, L. (2014). The summarized weighted mean of maxima and its application at the end of risk assessment process, Acta Polyt. Hungarica, 11(3): 167-180.

37. Quddus, M.A. (2012). Adoption of dairy farming technologies by small farm holders: practices and constraints, Bangladesh Journal Animal Science, 41(2): 124-135.

38. Ragin, C.C. (2000). Fuzzy-set in social science, London: the University of Chicago Press Ltd.

39. Rashid, H.A., Julfiquar, A.W. \& Ali, S. (2011). History, impact and current status of hybrid rice research, development and delivery in Bangladesh, Dhaka: Agricultural Advisory Society (AAS). 
40. Renn, O. (2008). Concept of risk: an interdisciplinary review. Paper presented in the ISA Conference, Barcelona, September, 3-10.

41. Rivza, S. Z. \& Rivza, P. (2013). Fuzzy-ANP based research on the risk assessment of biogas production from agricultural biomass, Paper presented in the international symposium on the analytical hierarchy process, Kualalumpur, June 23-26.

42. Ross, T.J. (2005). Fuzzy logic with engineering applications, New York: Wiley $\&$ Sons Ltd.

43. Sarwar, M.G., Islam, R., \& Monzoor, S. (2007). Women's rights to land in Bangladesh: roles, limitations and transformation, Dhaka: Unnayan Onneshan - The Innovators.

44. Shah, M.M. I., Grant, W. J. \& Stocklmayer, S. (2015), Farmers' perception of risk in cultivating hybrid rice in Bangladesh, S. Afr. J. Agric. Ext, 4(2):17-29.

45. Shaikh, M.A.Q. (2015, November, 15). Bangladesh Agriculture: Challenges Ahead", the Daily Star.

46. Siddique, A.B. (2015, October, 30). Sea level rising by 6-20mm each year, Dhaka Tribune.

47. Smithson, M. \& Verkuilen, J. (2006). Fuzzy set theory: applications in the social sciences, quantitative applications in the social sciences, CA: Sage, Belmont.

48. Soussan, J. \& Arriens, W.L. (2004). Poverty and water security: understanding how water affects the poor, Manila: Asian Development Bank.

49. Sultana, A. (2012). Rice marketing in Bangladesh: from the perspective of village study at cox's bazar district, African Journal of Agricultural Research, 7(45): $5995-6004$.

50. The Daily Star, (2011, the Daily Star). Climate and hunger: Bangladesh fifth most vulnerable country.

51. Uddin, M.F. 2012. Application of fuzzy logic in sociological research: an instance of potential payoff, Bangladesh e-Journal of Sociology, 9(2):7-18.

52. UN (2009). Disaster risk reduction in the United Nations: roles, mandates and areas of work of key United Nations entities, Washington DC: UN.

53. UN (2010). World population prospects: the 2008 revision, Washington DC: UN.

54. WB (2013). Warming climate to hit Bangladesh hard with sea level rise, more floods and cyclones, World Bank press release, June 19, Washington D.C., USA.

55. WB (2015). The World Bank data: Bangladesh", Available at http:/ http://data. worldbank.org/country/bangladesh (accessed 15 October, 2017)

56. Yu, J. \& Lee. S. (2012). A conflict-risk assessment model for urban regeneration projects using fuzzy-FMEA. KSCE Journal of Civil Engineering, 16 (7): 10931103.

57. Zadeh, L.A. (1965). Fuzzy Sets, Information and Control 8: 338-353. 


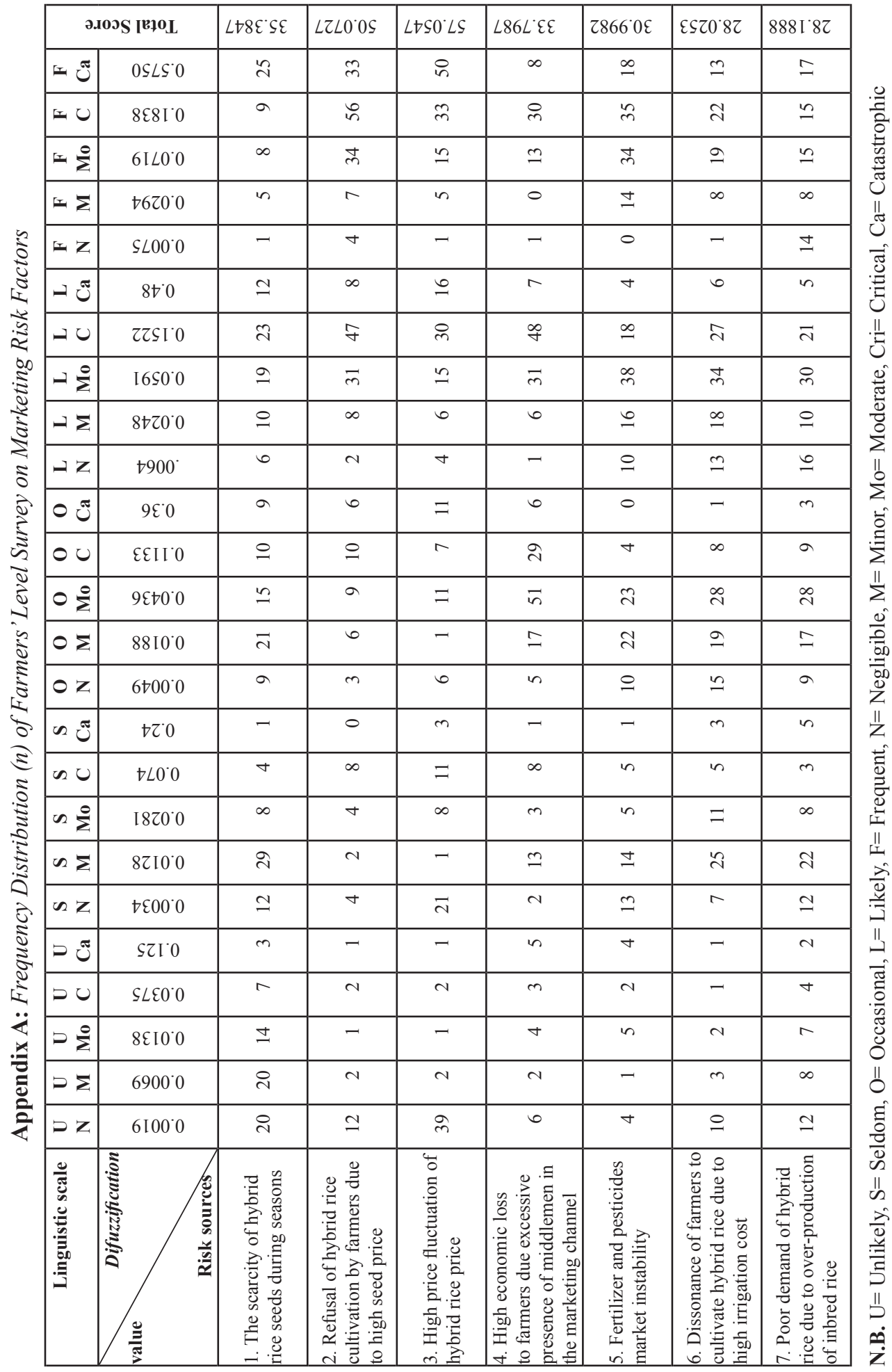

